\title{
Effect of antibiotic sensitivity on different cultured tissues and its significance in genetic transformation of cabbage Brassica oleracea
}

\author{
Geetika Gambhir*, Pankaj Kumar and D K Srivastava \\ Department of Biotechnology, Dr Y.S.Parmar University of Horticulture
} and Forestry Nauni, Solan-173230, Himachal Pradesh, India

\begin{abstract}
Successful plant transformation requires highly efficient regeneration protocol and suitable selection system. In this regard, the effect of kanamycin and cefotaxime was studied on cultured hypocotyl, cotyledon, leaf and petiole tissues of cabbage to look at the suitability of kanamycin resistance as a selectable marker and cefotaxime in controlling excessive bacterial growth during genetic transformation studies. Kanamycin sensitivity $\left(0-60 \mathrm{mgL}^{-1}\right)$ was checked by fresh weight of the explants (leaf and petiole) which was measured at the interval of 7 days till 35 days. Explants showed decrease in fresh weight as concentration of the kanamycin increased resulting in full or partial inhibition of shoot regeneration. A negative correlation was observed between the concentration of kanamycin and fresh weight of the explants at different intervals of time. Effect of different concentrations of cefotaxime (0-500 mgL-1) was studied on the regeneration potential in cotyledon and hypocotyl explants of cabbage and found no much effect of cefotaxime on regeneration potential. Effect of different concentrations of cefotaxime and kanamycin $\left(50 \mathrm{mgL}^{-1}\right)$ was studied on the growth of agrobacterial cells and regeneration potential of cotyledon and hypocotyl tissues after cocultivation. In both the explants, growth of agrobacterial cells were controlled at concentration of $400 \mathrm{mgL}^{-1}$ cefotaxime and maximum per cent shoot regeneration in cotyledon (35.55\%) and hypocotyl (48.15\%) was obtained on the best MS shoot regeneration medium supplemented with $400 \mathrm{mgL}^{-1}$ cefotaxime.The results indicate that kanamycin and cefotaxime act as an effective selective agents during genetic transformation studies.
\end{abstract}

KEY WORDS: CABBAGE, CEFOTAXIME, COTYLEDON, HYPOCOTYL, IN VITRO REGENERATION, LEAF, PETIOLE, KANAMYCIN

\section{ARTICLE INFORMATION:}

*Corresponding Author: geetikabt@gmail.com Received $21^{\text {st }}$ Oct, 2017

Accepted after revision $27^{\text {th }}$ Dec, 2017

BBRC Print ISSN: 0974-6455

Online ISSN: 2321-4007 CODEN: USA BBRCBA

. Thomson Reuters ISI ESC and Crossref Indexed Journal

NAAS Journal Score 2017: 4.31 Cosmos IF: 4.006

- A Society of Science and Nature Publication, 2017. All rights reserved.

Online Contents Available at: http//www.bbrc.in/

DOI: $10.21786 / \mathrm{bbrc} / 10.4 / 7$ 


\section{INTRODUCTION}

Brassica oleracea is an extremely diverse species of nutritionally rich and economically important vegetable crops including cabbage, cauliflower, broccoli, Kohlrabi and kale. Brassica oleracea L. var. capitata (Cabbage) is one of the most important vegetable in India, as India is next only to China in area and production of vegetables and occupies prime position in production of cabbage (FA0). It is cultivated in $0.245 \mathrm{M}$ ha with the total production of $5.167 \mathrm{M}$ mt and average productivity of $22.9 \mathrm{mt} /$ ha (NCPAH India, 2012). But quality and quantity of cabbage produce is challenged by many biotic and abiotic stresses including infestation of insects and pest. The major pest affecting cabbage production is the diamondback moth (Putella xylostella) (Jin et al., 2000). Total yield loss of cabbage in India due to infestation of insect and pest is about 16.87-58.83\% (Dhandapani et al., 2003). Massive quantities of synthetic insecticides are used, giving rise to major concerns about food and nutritional security and environmental pollution in addition to the high chemical and labor costs. Modern biotechnological tools could be of much significance to alleviate the negative effects of chemicals and synthetic pesticides. Application of plant genetic engineering using transgenic technology expressing foreign genes (insect resistant gene) could be an important aspect of integrated pest management. Two requirements for successful transformation are the ability to introduce desirable genes into the genome and the capacity to regenerate plants from the transformed cells (Kanwar and Kumar, 2011). As a preliminary step in efficient genetic transformation experiments involving the antibiotic sensitivity experiment (kanamycin resistance as a selectable marker and cefotaxime in controlling excessive bacterial growth).Genes encoding antibiotic resistance and herbicide tolerance are widely employed asselective markers to identify the rare transformed explants (de Vetten et al., 2003; Miki \&t McHugh, 2004; Kumar and Srivastava, 2016a). Selective agent concentration to be used in gene transfer should beoptimized prior to transformation to determine agent effective on shoot and rootregeneration and to determine lethal dose for each agent. The continued presence of Agrobacterium interferes with the growth, development,and rooting rates; and even it causes the necrosis of transformed explants (Tang et al., 2004). Moreover, elimination of Agrobacterium from transformants is a prerequisite inpreventing the possibility of gene release when these plants are transferred to soil (Barrett etal., 1997). Bacterial presence on putative transgenics may also result in false positivesduring molecular analyses. Most commonly used antibiotics for elimination of variousstrains of Agrobacterium are carbenicillin, cefotaxime and timentin (Nauerby et al.,
1997; Kumar and Srivastava, 2016b). The purpose of this study was to check the toxic level of kanamycin and cefotaxime on various explants of cabbage.

\section{MATERIAL AND METHODS}

\section{MEDIUM PREPARATION}

MS salts (macro and micro salts) and vitamins supplemented with $100 \mathrm{mgL}^{-1}$ meso-inositol, $3.0 \%$ sucrose and $0.8 \%$ agar-agar for solidification of media were used as basal medium. The selective media for kanamycin and cefotaxime sensitivity experiment was prepared by adding kanamycin (kanamac, Macleods Laboratory Pvt. Ltd., Mumbai, India) and cefotaxime into pre-sterilized molten MS regeneration medium (best shoot regeneration medium) of cabbage cv. Pride of India, under aseptic conditions by filter sterilization through $0.22 \mu \mathrm{m}$ pore size, Whatman ${ }^{\circledast}$ membrane filter. Different concentrations $\left(0,10,20,30,40,50\right.$ and $\left.60 \mathrm{mgL}^{-1}\right)$ of kanamycin was added into the medium to study the effect of antibiotic on the relative growth of cultured explants/tissues (leaf and petiole) of cabbage. Different concentrations $\left(100,200,300,400\right.$ and $\left.500 \mathrm{mgL}^{-1}\right)$ of cefotaxime were added into the medium to study the effect of antibiotic on the regeneration potential of cotyledon and hypocotyl explants.Different concentrations $(0,100,200,300$, $400,500 \mathrm{mgL}^{-1}$ ) of cefotaxime with $50 \mathrm{mgL}^{-1}$ kanamycin were added into the medium to study the effect of antibiotics on the growth of agrobacterial cells and regeneration potential of cotyledon and hypocotyl explants.

\section{INOCULATION OF EXPLANTS ON SELECTIVE MEDIA}

The leaf and petiole explants were excised from glasshouse grown 20-25 days old seedlingsof cabbage, surface sterilized by $0.1 \%$ of mercuric chloride for 3 mins followed by 3-4 washing with double distilled water and cut into small pieces and weighed on an electronic balance under aseptic conditions in the laminar flow cabinet. The initial fresh weight of the explants was recorded. The explants were cultured on the normal regeneration medium as control and on the selective regeneration medium containing different concentrations of kanamycin

The cotyledon and hypocotyl explants were excised from asepticallygrown seedlings (seven to nine days old), cut into small pieces and cultured on selective shoot regeneration medium (MS medium + 2.0mgL${ }^{1} \mathrm{Kn}+0.50 \mathrm{mgL}^{-1} \mathrm{NAA}$ ) for cotyledon explants and (MS medium $+1.5 \mathrm{mgL}^{-1} \mathrm{Kn}+0.25 \mathrm{mgL}^{-1} \mathrm{IAA}$ ) for hypocotyl explants containing different concentrations of cefotaxime, cefotaxime with $50 \mathrm{mgL}^{-1}$ kanamycin. The growth and differentiation of the explants were recorded. 


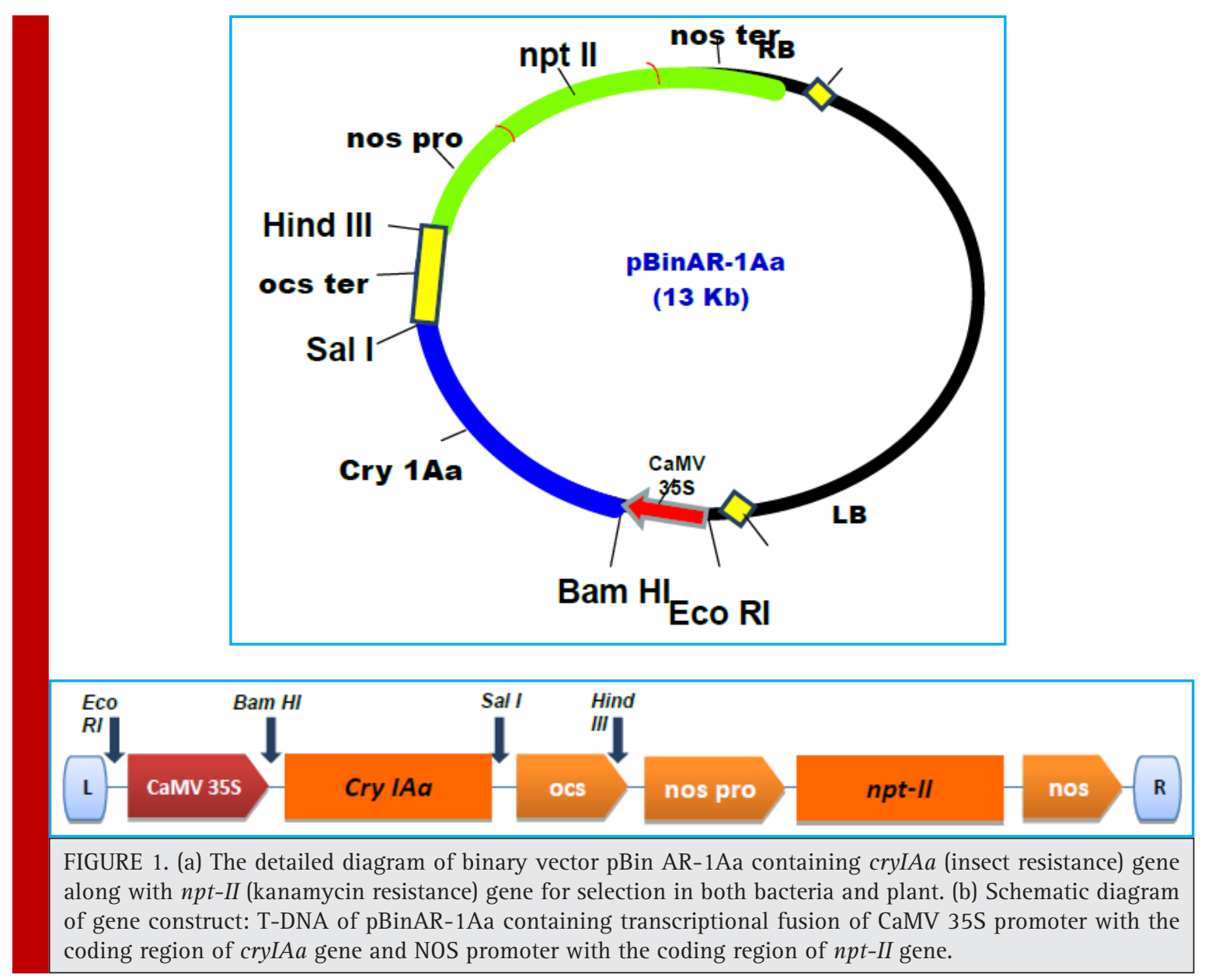

\section{MORPHOLOGICAL OBSERVATIONS AND MEASUREMENT OF RELATIVE GROWTH OF CULTURED TISSUES}

Morphological changes were observed in leaf and petiole explants from 0 to 35 days in culture. Fresh weight of both the explants (leaf and petiole) was measured at the interval of 7 days, from 0 day to 35 days in culture. Relative growth at 7 days interval was calculated on the normal as well as on the selective media.Morphological changes were observed in these tissues/explants at interval of seven days till shoot regeneration in culture. The effect of cefotaxime and kanamycin on the growth of agrobacterial cells and plant cells were recorded till shoot regeneration.

\section{RESULTS}

\section{KANAMYCIN SENSITIVITY IN LEAF AND PETIOLE TISSUES OF CABBAGE}

The leaf and petiole explants were excised from in vivo grown seedlings, surface sterilized and cut into small uniform pieces. Fresh weight of these explants were measured under Laminar air hood with proper aseptical conditions and then inoculated on MS selective shoot regeneration medium having different concentrations of kanamycin $\left(0,10,20,30,40,50\right.$ and $\left.60 \mathrm{mgL}^{-1}\right)$

The explants in control medium i.e. MS shoot regeneration medium without kanamycin were very healthy and showed appropriate growth on this medium. But, on the selective media at concentration as low as $10 \mathrm{mgL}^{-1}$ kanamycin, the colour of explant/tissue had changed to pale greenish yellow. In control experiment, adventitious shoot bud regeneration was observed after 30-35 days in culture, whereas no shoot regeneration or shoot bud formation was observed even after 5 weeks in leaf explants but in petiole explants little callusing at the initial stage but later on it turned into brownish black was recorded on culture in MS selective medium containing $10 \mathrm{mgL}^{-1}$ kanamycin. A gradual decline in fresh weight of leaf explants were recorded with increased concentration of kanamycin (10 to $60 \mathrm{mgL}^{-1}$ ) from 7-35 days. The maximum decline in fresh weight was observed at $50 \mathrm{mgL}^{-1}$ kanamycin in leaf explants, whereas in case of control (MS regeneration medium without kanamycin) there was a 


\begin{tabular}{l} 
Table 1. Effect of different concentrations of kanamycin on the relative growth (fresh weight) of leaf explants of \\
cabbage (Brassica oleracea L. var. capitata cv. Pride of India) on MS Basal full strength + 1.5 mg/l BAP+ 0.50mg/l \\
NAA. \\
\hline \multirow{2}{*}{ S. No. }
\end{tabular}

maximum increase in fresh weight of explants (Table 1 and 2 ) (Fig. 2A-F).

Statistical analysis of the recorded data showed that there was a significant difference between fresh weights of all six treatments of kanamycin concentrations $(0$ to $60 \mathrm{mgL}^{-1}$ ). Negative coefficient of correlation was observed between different concentrations of kanamycin and fresh weight of explants/tissue. It indicates that kanamycin has an inhibitory effect on the growth of cultured tissues as it is a potent inhibitor of protein synthesis.(Fig.1 (A-F))

\section{EFFECT OF CEFOTAXIME ON SHOOT REGENERATION FROM COTYLEDON AND HYPOCOTYL EXPLANTS}

In cotyledon explants, the maximum per cent (88\%) shoot regeneration with average number of shoots (2.66) were obtained on MS shoot regeneration medium with $300 \mathrm{mgL}^{-1}$ cefotaxime. With the increase in the concentrations of cefotaxime, percent shoot regeneration was same till $300 \mathrm{mgL}^{-1}$ cefotaxime but increased at 300 $\mathrm{mgL}^{-1}$ cefotaxime then the percent shoot regeneration

\begin{tabular}{|c|c|c|c|c|c|c|c|c|}
\hline \multirow{3}{*}{ S. No. } & \multirow{3}{*}{ Days } & \multicolumn{7}{|c|}{ Average fresh weight of leaf explants/callus of cabbage (mg) } \\
\hline & & \multicolumn{7}{|c|}{ Kanamycin concentrations (mg/l) } \\
\hline & & 0 & 10 & 20 & 30 & 40 & 50 & 60 \\
\hline 1. & 0 & $5.66 \pm 0.41$ & $5.00 \pm 0.29$ & $5.60 \pm 0.00$ & $5.40 \pm 0.12$ & $5.00 \pm 0.58$ & $5.80 \pm 0.23$ & $5.20 \pm 0.12$ \\
\hline 2. & 7 & $17.17 \pm 0.41$ & $11.00 \pm 0.29$ & $14.20 \pm 0.00$ & $12.46 \pm 0.12$ & $11.32 \pm 0.58$ & $7.92 \pm 0.23$ & $6.68 \pm 0.12$ \\
\hline 3. & 14 & $52.67 \pm 0.41$ & $39.10 \pm 0.29$ & $32.87 \pm 0.20$ & $23.36 \pm 0.12$ & $19.32 \pm 0.58$ & $14.62 \pm 0.23$ & $11.28 \pm 0.12$ \\
\hline 4. & 21 & $125.50 \pm 0.87$ & $103.70 \pm 0.29$ & $92.30 \pm 0.21$ & $65.26 \pm 0.12$ & $41.12 \pm 0.58$ & $22.62 \pm 0.23$ & $16.28 \pm 0.12$ \\
\hline 5. & 28 & $215.50 \pm 0.87$ & $158.90 \pm 0.22$ & $126.00 \pm 0.21$ & $80.36 \pm 0.12$ & $50.69 \pm 0.79$ & $24.82 \pm 0.23$ & $16.08 \pm 0.12$ \\
\hline 6. & 35 & $366.40 \pm 0.87$ & $257.50 \pm 0.22$ & $188.00 \pm 0.21$ & $110.10 \pm 0.12$ & $58.32 \pm 0.58$ & $24.52 \pm 0.23$ & $14.98 \pm 0.12$ \\
\hline $\mathrm{CD}_{0.05}$ & \multicolumn{8}{|c|}{0.5396} \\
\hline $\mathrm{SE}_{ \pm}$ & \multicolumn{8}{|c|}{0.3816} \\
\hline
\end{tabular}




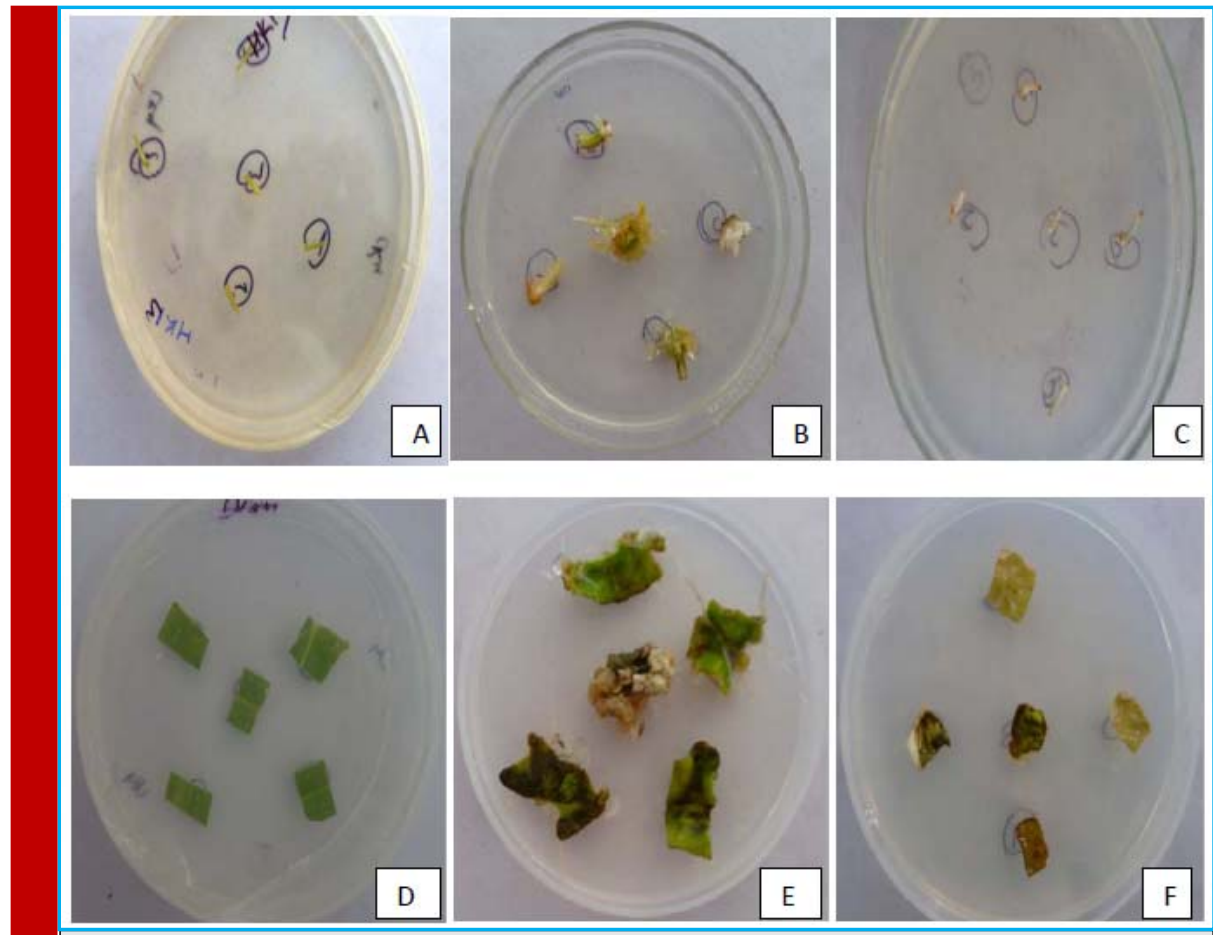

FIGURE 2. (a) Petiole explants cultured on selective medium (MS basal $+2.0 \mathrm{mg} / \mathrm{l} \mathrm{Kn}$ $+0.25 \mathrm{mg} / \mathrm{l} \mathrm{NAA}+50 \mathrm{mg} / \mathrm{l} \mathrm{Kanamycin)}$ at day 0 in culture. (b) Petiole explants showing shoot initiation on selective medium (MS basal $+2.0 \mathrm{mg} / \mathrm{l} \mathrm{Kn}+0.25 \mathrm{mg} / \mathrm{l} \mathrm{NAA}+$ $10 \mathrm{mg} / \mathrm{l}$ Kanamycin) at 35 days of culturing. (c) Petiole explants turned brown (dead) on selective medium (MS basal $+2.0 \mathrm{mg} / \mathrm{l} \mathrm{Kn}+0.25 \mathrm{mg} / \mathrm{l} \mathrm{NAA}+50 \mathrm{mg} / 1$ Kanamycin) at 35 days of culturing. (d) Leaf explants cultured on selective medium (MS basal $+1.50 \mathrm{mg} / \mathrm{l} \mathrm{BAP}+0.50 \mathrm{mg} / \mathrm{l} \mathrm{NAA}+50 \mathrm{mg} / \mathrm{l} \mathrm{Kanamycin)at} \mathrm{day} 0$ in culture. (e) Leaf explants showing callus initiation on selective medium (MS basal $+1.50 \mathrm{mg} / \mathrm{l} \mathrm{BAP}+$ $0.50 \mathrm{mg} / \mathrm{l} \mathrm{NAA}+10 \mathrm{mg} / \mathrm{l} \mathrm{Kanamycin}$ ) at 21 days of culturing. (f) Leaf explants turned brown (dead) on selective medium (MS basal $+1.50 \mathrm{mg} / 1 \mathrm{BAP}+0.50 \mathrm{mg} / 1 \mathrm{NAA}+$ $50 \mathrm{mg} / \mathrm{l} \mathrm{Kanamycin)}$ at 35 days of culturing.

Table 3. Effect of different concentrations of cefotaxime on the relative growth of cotyledon explants of cabbage (Brassica oleracea L. var. capitata cv.Pride of India) (without co-cultivation)

\begin{tabular}{|l|l|l|l|}
\hline Sr. No. & Cefotaxime concentration & $\begin{array}{l}\text { Average number of shoots } \\
\text { regenerated per explants }\end{array}$ & $\begin{array}{l}\text { Percent shoot } \\
\text { regeneration }\end{array}$ \\
\hline 1 & MS basal medium $+2.0 \mathrm{mg} / \mathrm{l} \mathrm{Kn}+0.5 \mathrm{mg} / \mathrm{l} \mathrm{NAA}+0 \mathrm{mg} / \mathrm{l}$ & 2.597 & $84.44(66.87)$ \\
\hline 2 & MS basal medium $+2.0 \mathrm{mg} / \mathrm{l} \mathrm{Kn}+0.5 \mathrm{mg} / \mathrm{l} \mathrm{NAA}+100 \mathrm{mg} / \mathrm{l}$ & 2.460 & $84.44(66.87)$ \\
\hline 3 & MS basal medium $+2.0 \mathrm{mg} / \mathrm{l} \mathrm{Kn}+0.5 \mathrm{mg} / \mathrm{l} \mathrm{NAA}+200 \mathrm{mg} / \mathrm{l}$ & 2.579 & $84.44(66.87)$ \\
\hline 4 & MS basal medium $+2.0 \mathrm{mg} / \mathrm{l} \mathrm{Kn}+0.5 \mathrm{mg} / \mathrm{l} \mathrm{NAA}+300 \mathrm{mg} / \mathrm{l}$ & 2.666 & $88.88(70.73)$ \\
\hline 5 & MS basal medium $+2.0 \mathrm{mg} / \mathrm{l} \mathrm{Kn}+0.5 \mathrm{mg} / \mathrm{l} \mathrm{NAA}+400 \mathrm{mg} / 1$ & 2.423 & $80.00(63.44)$ \\
\hline 6 & MS basal medium $+2.0 \mathrm{mg} / \mathrm{l} \mathrm{Kn}+0.5 \mathrm{mg} / \mathrm{l} \mathrm{NAA}+500 \mathrm{mg} / \mathrm{l}$ & 2.597 & $84.44(66.87)$ \\
\hline $\mathrm{CD}_{0.05}$ & 0.156 & & \\
\hline $\mathrm{SE}_{ \pm}$ & 0.078 & $5.66(3.435)$ &
\end{tabular}




\begin{tabular}{|c|c|c|c|}
\hline Sr. No. & Cefotaxime concentration & $\begin{array}{l}\text { Average number of shoots } \\
\text { regenerated per explants }\end{array}$ & $\begin{array}{l}\text { Percent shoot } \\
\text { regeneration }\end{array}$ \\
\hline 1 & MS basal medium $+1.5 \mathrm{mg} / \mathrm{l} \mathrm{Kn}+0.25 \mathrm{mg} / \mathrm{l} \mathrm{IAA}+0 \mathrm{mg} / \mathrm{l}$ & 2.460 & 90.73(73.47) \\
\hline 2 & MS basal medium $+1.5 \mathrm{mg} / \mathrm{l} \mathrm{Kn}+0.25 \mathrm{mg} / \mathrm{l} \mathrm{IAA}+100 \mathrm{mg} / \mathrm{l}$ & 2.393 & 87.03(69.59) \\
\hline 3 & MS basal medium $+1.5 \mathrm{mg} / \mathrm{l} \mathrm{Kn}+0.25 \mathrm{mg} / \mathrm{l} \mathrm{IAA}+200 \mathrm{mg} / \mathrm{l}$ & 2.460 & 87.03(69.59) \\
\hline 4 & MS basal medium $+1.5 \mathrm{mg} / \mathrm{l} \mathrm{Kn}+0.25 \mathrm{mg} / \mathrm{l} \mathrm{IAA}+300 \mathrm{mg} / \mathrm{l}$ & 2.367 & $81.49(64.56)$ \\
\hline 5 & MS basal medium $+1.5 \mathrm{mg} / \mathrm{l} \mathrm{Kn}+0.25 \mathrm{mg} / \mathrm{l} \mathrm{IAA}+400 \mathrm{mg} / \mathrm{l}$ & 2.466 & 87.03(69.59) \\
\hline 6 & MS basal medium + 1.5mg/l Kn + 0.25mg/l IAA +500 mg/l & 2.533 & 87.03(69.59) \\
\hline $\mathrm{CD}_{0.05}$ & $6.589(4.091)$ & & \\
\hline $\mathrm{SE}_{ \pm}$ & $3.024(1.915)$ & & \\
\hline
\end{tabular}

decreased. All the observations were recorded after 45 days of inoculation of explants. Whereas, in case of hypocotyl explants, very interesting and different shoot regeneration was observed on the same medium on dif-

ferent segments of hypocotyl explants. The maximum per cent (90.73\%) shoot regeneration with average number of shoots (2.460) were obtained on MS shoot regeneration medium with $0 \mathrm{mgL}^{-1}$ cefotaxime. Percent shoot
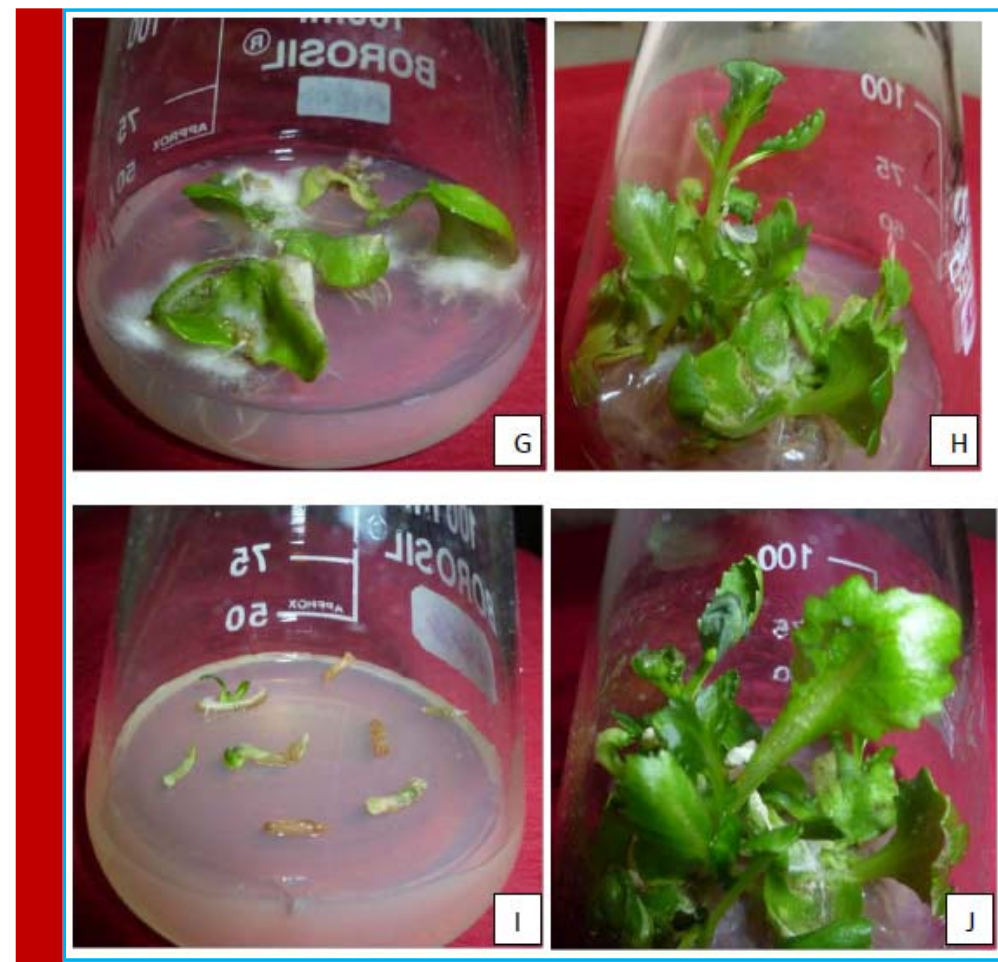

FIGURE 2(Continued). (g) Cotyledon explants showing callus initiation on selective medium (MS basal $+2.0 \mathrm{mg} / \mathrm{l} \mathrm{Kn}+0.50 \mathrm{mg} / \mathrm{l} \mathrm{NAA}+$ $500 \mathrm{mg} / \mathrm{l}$ Cefotaxime) after 13 days of culturing. (h) Shoot elongation from cotyledon explants on selective medium (MS basal $+2.0 \mathrm{mg} / \mathrm{l} \mathrm{Kn}$ $+0.50 \mathrm{mg} / \mathrm{l} \mathrm{NAA}+500 \mathrm{mg} / \mathrm{l}$ Cefotaxime) after 45 days of culturing. (i) Hypocotyl explants showing shoot initiation on selective medium (MS basal $+1.5 \mathrm{mg} / \mathrm{l} \mathrm{Kn}+0.25 \mathrm{mg} / \mathrm{l} \mathrm{IAA}+500 \mathrm{mg} / \mathrm{l}$ Cefotaxime) after 22 days of culturing. (j) Shoot elongation from hypocotyl explants on selective medium (MS basal $+1.5 \mathrm{mg} / \mathrm{l} \mathrm{Kn}+0.25 \mathrm{mg} / \mathrm{l} \mathrm{IAA}+500 \mathrm{mg} / \mathrm{l}$ Cefotaxime) after 50 days of culturing. 
Table 5. Effect of various concentrations of cefotaxime and kanamycin $(50 \mathrm{mg} / \mathrm{l})$ on the regeneration potential of cotyledon explants in cabbage (Brassica oleracea L. var. capitata cv. Pride of India)(after co-cultivation)

\begin{tabular}{|l|l|l|l|}
\hline S. no. & Cefotaxime concentration & $\begin{array}{l}\text { Average number of } \\
\text { shoots per explants }\end{array}$ & $\begin{array}{l}\text { Per cent shoot } \\
\text { regeneration }\end{array}$ \\
\hline 1. & MS basal medium $+2 \mathrm{mg} / \mathrm{l} \mathrm{Kn}+0.50 \mathrm{mg} / \mathrm{l} \mathrm{NAA}+50 \mathrm{mg} / \mathrm{l} \mathrm{Kanamycin}+0 \mathrm{mg} / \mathrm{l}$ & 0.000 & $0.00(0.00)$ \\
\hline 2. & MS basal medium $+2 \mathrm{mg} / \mathrm{l} \mathrm{Kn}+0.50 \mathrm{mg} / \mathrm{l} \mathrm{NAA}+50 \mathrm{mg} / \mathrm{l} \mathrm{Kanamycin}+100 \mathrm{mg} / \mathrm{l}$ & 0.000 & $0.00(0.00)$ \\
\hline 3. & MS basal medium $+2 \mathrm{mg} / \mathrm{l} \mathrm{Kn}+0.50 \mathrm{mg} / \mathrm{l} \mathrm{NAA}+50 \mathrm{mg} / \mathrm{l} \mathrm{Kanamycin}+200 \mathrm{mg} / \mathrm{l}$ & 0.000 & $0.00(0.00)$ \\
\hline 4. & MS basal medium $+2 \mathrm{mg} / \mathrm{l} \mathrm{Kn}+0.50 \mathrm{mg} / \mathrm{l} \mathrm{NAA}+50 \mathrm{mg} / \mathrm{l} \mathrm{Kanamycin}+300 \mathrm{mg} / \mathrm{l}$ & 0.400 & $16.66(19.16)$ \\
\hline 5. & MS basal medium $+2 \mathrm{mg} / \mathrm{l} \mathrm{Kn}+0.50 \mathrm{mg} / \mathrm{l} \mathrm{NAA}+50 \mathrm{mg} / \mathrm{l} \mathrm{Kanamycin}+400 \mathrm{mg} / \mathrm{l}$ & 2.930 & $35.55(36.59)$ \\
\hline 6. & MS basal medium $+2 \mathrm{mg} / \mathrm{l} \mathrm{Kn}+0.50 \mathrm{mg} / \mathrm{l} \mathrm{NAA}+50 \mathrm{mg} / \mathrm{l} \mathrm{Kanamycin}+500 \mathrm{mg} / \mathrm{l}$ & 1.35 & $22.22(28.07)$ \\
\hline $\mathrm{CD}_{0.05}$ & \multicolumn{2}{|c|}{$0.330 \quad 3.140(1.998)$} & \\
\hline $\mathrm{SE}_{ \pm}$ & $0.1502 .024(1.347)$ & & \\
\hline
\end{tabular}

regeneration decreased in medium supplemented with $300 \mathrm{mgL}^{-1}$ cefotaxime whereas remain constant at 100 , 200, 400 and $500 \mathrm{mgL}^{-1}$ cefotaxime but maximum average number of shoots (2.466) were observed in medium supplemented with $400 \mathrm{mgL}^{-1}$ cefotaxime(Table 3 and $4 \mathrm{\& t}$ Fig. 1(G-J))

\section{EFFECT OF CEFOTAXIME AND KANAMYCIN (50MGL ${ }^{-1}$ ) ON THE REGENERATION POTENTIAL OF CABBAGE AFTER CO-CULTIVATION}

The effect of varying concentrations of cefotaxime with same concentrations of kanamycin was studied on the regeneration efficiency and their capability to control the overgrowth of agrobacterial cells after co-cultivation. At lower concentrations (0, 100, 200, $\left.300 \mathrm{mgL}^{-1}\right)$ of cefotaxime showed overgrowth of agrobacterial cells and at higher concentrations of cefotaxime, the agro- bacterial cells growth was completely inhibited. Per cent shoot regeneration (35.55\%) and (48.15\%) and average number of shoots (2.93) and (1.770) per plant was found maximum in $400 \mathrm{mgL}^{-1}$ cefotaxime with $50 \mathrm{mgL}^{-1} \mathrm{kana}^{-}$ mycin for cotyledon and hypocotyls explants respectively. At lower concentrations of cefotaxime, all the explants died due to uncontrolled growth of agrobacterial cells. At the concentration of $300 \mathrm{mgL}^{-1}$ cefotaxime the density of agrobacterial cells started decreasing(Table 5 and 6).

\section{DISCUSSION}

Kanamycin resistance gene is most widely used selectable marker for plant cell transformation and sensitivity of a particular species to kanamycin is a key element in the development of any new transformation system in

Table 6. Effect of various concentrations of cefotaxime and kanamycin $(50 \mathrm{mg} / \mathrm{l})$ on the regeneration potential of hypocotyl explants in cabbage (Brassica oleracea L. var. capitata cv. Pride of India) (after co-cultivation)

\begin{tabular}{|c|c|c|c|}
\hline S. No. & Cefotaxime concentration & $\begin{array}{l}\text { Average number of } \\
\text { shoots per explants }\end{array}$ & $\begin{array}{l}\text { Per cent shoot } \\
\text { regeneration }\end{array}$ \\
\hline 1. & MS basal medium $+1.5 \mathrm{mg} / \mathrm{l} \mathrm{Kn}+0.25 \mathrm{mg} / \mathrm{l} \mathrm{IAA}+50 \mathrm{mg} / 1 \mathrm{Kanamycin}+0 \mathrm{mg} / \mathrm{l}$ & 0.000 & $0.00(0.00)$ \\
\hline 2. & MS basal medium $+1.5 \mathrm{mg} / \mathrm{l} \mathrm{Kn}+0.25 \mathrm{mg} / \mathrm{l} \mathrm{IAA}+50 \mathrm{mg} / \mathrm{l} \mathrm{Kanamycin}+100 \mathrm{mg} / \mathrm{l}$ & 0.000 & $0.00(0.00)$ \\
\hline 3. & MS basal medium + 1.5mg/l Kn + 0.25mg/l IAA+ 50mg/l Kanamycin+200 mg/l & 0.000 & $0.00(0.00)$ \\
\hline 4. & MS basal medium + 1.5mg/l Kn + 0.25mg/l IAA+ 50mg/l Kanamycin+300 mg/l & 0.700 & $20.33(26.38)$ \\
\hline 5. & MS basal medium + 1.5mg/l Kn + 0.25mg/l IAA+ 50mg/l Kanamycin+400 mg/l & 1.770 & $48.15(43.94)$ \\
\hline 6. & MS basal medium + 1.5mg/l Kn + 0.25mg/l IAA+ 50mg/l Kanamycin+500 mg/l & 1.250 & $35.18(36.37)$ \\
\hline $\mathrm{CD}_{0.05}$ & \multicolumn{3}{|l|}{$0.410 \quad 4.510(3.098)$} \\
\hline $\mathrm{SE}_{ \pm}$ & $2.740(1.701)$ & & \\
\hline
\end{tabular}


which a kanamycin resistance gene will be employed. The genetically engineered Agrobacterium strain which we have used in the present study has two genes i.e. cry IA $a$ and npt-II.Kanamycin sensitivity of cultured tissue of leaf and petiole explants of cabbage had shown similar results, i.e. both explants are highly sensitive to kanamycin even as low as $10 \mathrm{mgL}^{-1}$ concentration of kanamycin. The non-transformed tissues did not survive on the selective medium containing Kanamycin during transformation experiment. Srivastava (1997) reported that cells which are not transformed get killed on selective media in such a manner that they become toxic to adjacent transformed cells, resulting in inhibition of the whole callus. Similar results were also reported by Eimert and Siegemund (1992). The alternating culture and repeated selection seem to be necessary for differentiation of transformed shoots against the inhibitory effect of kanamycin and elimination of escapes. The explants in control medium were very healthy and showed appropriate growth on the medium, but on selective medium at concentration as low as $20 \mathrm{mgL}^{-1}$ kanamycin, the color of the explants/tissues had changed to greenish yellow and finally turned brown after 35 days of culture of broccoli (Pankaj et al., 2017).

Only $35 \mathrm{mgL}^{-1}$ of kanamycin totally inhibit shoot differentiation from co-cultivated thin cell layer explants of Brassica napus (Charest et al., 1988), 20 $\mathrm{mgL}^{-1}$ inhibits shoot induction from stem segments (Pua et al., 1987) and $50 \mathrm{mgL}^{-1}$ inhibits shoot regeneration of Brassica oleracea (Bhalla and Smith, 1998; Dixit et al., 1998; Bhattacharya et al., 2002; Sharma and Srivastava, 2003; Singh and Srivastava, 2003; Cao et al., 2008; Deng-Xia et al., 2011; Kumar and Srivastava, 2016b, Sharma and Sirvastava 2017).Kang et al. (2002) reported that for cotyledon explants of Chinese cabbage, shoot induction was not significantly affected by kanamycin at $1.0 \mathrm{mgL}^{-1}$ but the number of shoots formed was significantly reduced at $2.0 \mathrm{mgL}^{-1}$ and no shoot were regenerated from any explants at $6.0 \mathrm{mgL}^{-1}$ or higher and similar results were obtained in case of hypocotyl explants. Paul et al. (2005) reported that hypocotyl explants of cabbage showed inhibition in growth on medium containing $20 \mathrm{mgL}^{-1}$ kanamycin. Bhalla and Smith (1998) also reported that exposure of regenerated green shoots to a higher kanamycin concentration on medium containing low sucrose was used to eliminate non-transformed shoots. Bhau and Wakhlu (2001) reported callus of Coryphantha elephantidens showed less or no inhibition in callus growth at lower concentration of kanamycin whereas at higher concentration $\left(10,15,20 \mathrm{mgL}^{-1}\right)$ observed inhibited callus growth. In contrast some of the monocotyledons indicate a high level of natural resistance to kanamycin. More than $800 \mathrm{mgL}^{-1}$ is required to inhibit growth of cell suspension cultures of several species of Graminae
(Hauptman et al., 1988). Oz et al. (2009) used higher concentration of kanamycin $\left(200 \mathrm{mgL}^{-1}\right)$ for inhibition of non-transformed tissues of chickpea. Kanwar and Kumar (2011) used higher concentrations of kanamycin (100 $\mathrm{mgL}^{-1}$ ) for selection of transformed callus/ tissues of Dianthus caryophyllus L.

The effect of different concentrations of cefotaxime has been studied separately on the regeneration potential of cabbage. In the present investigations, maximum per cent shoot regeneration was obtained on the best shoot regeneration medium with $300 \mathrm{mgL}^{-1}$ cefotaxime in cotyledon explants. It has been observed that the increase in the concentration of cefotaxime showed no much effect on regeneration potential.Cefotaxime has potential to increase the growth, regeneration and embryogenesis in vitro. Cefotaxime promoted growth and morphogenesis in callus cultures of wheat and barley (Mathias and Boyd, 1986; Mathias and Mukasa, 1987). Yepes and Aldwinekle (1994) evaluated the effect of antibiotics on morphogenesis of apple. Similar studies were also carried out by Humara et al. (1999) and they observed that $250 \mu \mathrm{g}$ $\mathrm{ml}^{-1}$ cefotaxime enhanced the shoot regeneration capacity. Danilova and Dolgikh (2004) reported stimulatory effect of the antibiotic cefotaxime on plant regeneration in maize tissue culture which enhanced its morphogenesis. The highest increase in the number of regenerated shoots was observed at the antibiotic concentration of $150 \mathrm{mgL}^{-1}$. Kaur et al. (2008) obtained enhanced in vitro shoot multiplication and elongation in sugarcane used at the rate of 250 and $500 \mathrm{mgL}^{-1}$ cefotaxime in the medium. In hypocotyl explants, no increase in shoot regeneration potential was observed on medium supplemented with different concentration of cefotaxime. Borrelli et al. (1999) reported similar results that cefotaxime did not affect callus growth in durum wheat. Whereas, Ahmad et al. (2012) observed that with the increase of cefotaxime concentration the transformation frequency was lowered and most of the explants of Solanum tuberosum L. were dead.

\section{CONCLUSION}

Selection and identification of transformed cells and tissues are vital steps of genetic transformation which prove to be helpful in improving the selection and transformation efficiency. This study thus reports an efficient antibiotic selection protocol for Agrobacterium-mediated cabbage transformation.

\section{ACKNOWLEDGEMENTS}

Our sincere thanks to Professor and Head, Dept. of Vegetable Science of Dr. Y.S. Parmar University of Horticulture and Forestry, Solan, India for providing certified seeds of cabbage cv. Pride of India. 


\section{REFERENCES}

AhmadMZ, Hussain I, MuhammadA, Ali S, Ali GM, RoomiZ, Zia MA, Ijaz A. 2012. Factor affecting Agrobacterium-mediated transformation of rice chitinase gene in Solanum tuberosum L.African Journal of Biotechnology 11(41): 9716-9723.

Anonymous. 2012. FA0: Economic and Social Department: The Statistical Division. United Nations.

Barrett CE, Cobb R, McNicol A, Lyon G.1997. A risk assessment study of plant genetictransformation using Agrobacterium and implications for analysis of transgenic plants. PlantCell Tissue and Organ Culture 47: 135-144.

Bhalla PL, Smith N. 1998. Agrobacterium tumefaciens-mediated transformation of cauliflower (Brassica oleracea var. botrytis). Molecular Breeding 4:531-541.

Bhattacharya RC, Viswakarma, BhatSR, Kirti PB, ChopraVL. 2002. Development of insect-resistance transgenic cabbage plants expressing a synthetic cry $I A(b)$ gene from Bacillus thuringiensis. Current Science 83(2): 146-150.

BhauBS, Wakhlu AK. 2001. Effect of some antibiotics on in vitro morphogenetic response form callus culture of Coryphantha elephantidens. Biology Plantarum44(1): 19-24.

BorrelliGM, Difonzo N, LupottoE. 1999. Agrobacterium-mediated transformation of wheat. Journal of Plant Phyisology 140: 372-374.

CaoJ, SheltonAM, Earle ED. 2008. Sequential transformation to pyramid two Bt genes in vegetable Indian mustard (Brassica juncea L.) and its potential for control of diamondback moth larvae. Plant Cell Reports 27:479-487.

Charest PJ, HolbrookLA, Gabard J, Iyer VN, Miki BL. 1988. Agrobacterium-mediated transformation of thin cell layer explants from Brassica napus L. Theoritical Applied Genetics 75: 438-445.

Danilova SA, DolgikhYI. 2004. The stimulatory effect of the antibiotic cefotaxime on plant regeneration in maize tissue culture. Russian Journal ofPlant Physiology 51 (4): 559562.

De Vetten N, Wolters AM, Raemakers K,Van der Meer I, Ter Stege R, Heeres E, Heeres P, Visser P. 2003. A transformation method for obtaining marker-free plants of a crosspollinatingand vegetatively propagated crop. Nature Biotechnology21: 439-442.

Deng-Xia Y, Lei C, Yu-Mei L, Mu Z, Yang-Yong Z, Zhi-Yuan F, Li-MeiY.2011. Transformation of cabbage (Brassica oleracea L. var. capitata) with Bt cry1Ba3 gene for control of diamondback moth. Agriculture Sciences inChina 10(11): 1693-1700.

Dhandapani N, UmeshchandraRS, Murugan M. 2003. Bio-intesive pest management (BIPM) in major vegetable crops: an Indian perspective. Journal of Food Agriculture and Environment 1(2):333-339.

Dixit S, Srivastava DK, SharmaDR. 1998. Genetic transformation in cauliflower (Brassica oleracea var. botrytis cv. Pusa Snow Ball). In: National Symposium on Biotechnology in Agriculture and Environment, Abstract p. 2.
Eimert K, Siegemund F. 1992. Transformation of cauliflower (Brassica oleracea L. var. botrytis) - an experimental survey. Plant Molecular Biology 19: 485-490.

Hauptman RM, VasilV, Ozias-Akins P, TabaeizadehZ, RogersSG, FraleyRT, HorschRB, Vasil IK. 1988. Evaluation of selectable markers for obtaining stable transformants in the Graminae. Plant Physiology 86: 602-606.

HumaraJM, LopezM, OrdasRJ. 1999. Agrobacterium tumefaciens-mediated transformation of Pinus pinea L. cotyledons: An assessment of factors influencing the efficiency of UidA gene transfer. Plant Cell Reports 19(1): 51-58.

JinRG, Liu YB, Tabashnik BE, Borthakur D. 2000. Development of transgenic cabbage (Brassica oleracea var. capitata) for insect resistance by Agrobacterium tumefaciens - mediated transformation. In vitro Cellular and Developmental BiologyPlant36 (4): 231-237.

KangBK, KimSY, ParkYD. 2002. Effects of $\mathrm{AgNO}_{3}$, pH, agar concentrations and dark treatments on shoot induction from cotyledon and hypocotyl explants of Chinese cabbage. Korean Journal ofHorticultre Science and Technology 20 (4):309313.

KanwarJK, Kumar S. 2011. Recovery of Transgenic Plants by Agrobacterium-mediated Genetic Transformation in Dianthus caryophyllus L. (carnation). Advances in Applied Science Research 2(2): 357-366.

Kaur A, GillMS, Ruma D, Gosal SS. 2008. Enhanced in vitro shoot multiplication and elongation in sugarcane using cefotaxime. Sugar Technology 10(1):60-64.

Kumar P, Srivastava DK. 2016a.Biotechnological advancement in genetic improvement of broccoli (Brassica oleracea L. var. italica), an important vegetable crop: A review.BiotechnologyLetters38 (7):1049-1063.

Kumar P, Srivastava DK. 2016b Biotechnological application in in vitro plant regeneration studies of Broccoli (Brassica oleracea l. var. italica), an important vegetable crop.Biotechnology Letters 38(4):561-571.

Kumar P, Gaur A, Srivastava DK. 2017. Agrobacterium - mediated insect resistance gene (cry1Aa) transfer studies pertaining to antibiotic sensitivity on cultured tissues of broccoli (Brassica oleracia L. var. italica): an important vegetable crop. International Journal of Vegetable Science, doi: 10.1080/19315260.2017.1334734

Mathias RJ,Mukasa C.1987. The effect of cefotaxime on the growth and regeneration of callus from four varieties of barley (Hordeum vulgate L.). Plant Cell Reports 6:454-457.

Mathias RJ, BoydLA.1986. Cefotaxime stimulates callus growth, embryogenesis and regeneration in hexaploid bread wheat (Triticum aestivum L. em Thell). Plant Science46: 217233

Miki B, McHughS. 2004. Selectable marker genes in transgenic plants: applications, alternatives and biosafety. Journal of Biotechnology 107: 193-232.

Nauerby B, BillingK, WyndaeleR. 1997. Influence of the antibiotic timentin on plantregeneration compared to carbenicillin 
and cefotaxime in concentrations suitable forelimination of Agrobacterium tumefaciens. Plant Science123: 169-177.

Oz MT, Eyidoğan F, Yücel M, Öktem HA. 2009. Optimized selection and regeneration conditions for Agrobacterium-mediated transformation of chickpea cotyledonary nodes. Pakistan Journal of Botany4: 2043-2054.

PaulA, SharmaSR, Sresty TVS, Devi S, Bala S, KumarPS, PardhaSP, Frutos R, AltosaarI, KumarPA. 2005. Transgenic cabbage (Brassica oleracea var. capitata) resistant to diamondback moth (Plutella xylostella). Indian Journal of Biotechnology 4: 72-77.

PuaEC, Mehra-Palta A, Nagy F, Chua NH. 1987. Transgenic plants of Brassica napus L. Biotechnology 5: 815-817.

SharmaS, SrivastavaDK. 2003. Plant regeneration and genetic transformation studies in cabbage (Brassica oleracea L. var. capitata). In: Biotechnology strategies in Agro-processing, Marwaha S S and J K Arora, Asiatech Publishers Inc, New Delhi pp. 370-377.

Sharma S, and Srivastava DK. 2017. Agrobacterium-mediated fungal resistance gene transfer studies pertaining to antibiotic sensitivity on cultured tissues of lettuce (Lactuca sativa L. cv. Solan kriti). International Journal of Current Microbiology and Applied Sciences 6:1687-1698.

Singh N, SrivastavaDK. 2003. Genetic transformation studies in cabbage (Brassica oleracea L.var. capitata cv. Pride of India). In: Proceedings of $2^{\text {nd }}$ International Congress of Plant Physiology. Abstract No. S11-P20, pp. 468.

Srivastava DK. 1997. Agrobacterium-mediated gene transfer in plants - a review. In: Trends in plant tissue culture and biotechnology, L K Pareek (ed), Agrobotanical Publication, India, pp. 17-30.

Tang W, LuoH, Newton RJ. 2004. Effects of antibiotics on the elimination ofAgrobacterium tumefaciens from loblolly pine (Pinus taeda) zygotic embryo explants and ontransgenic plant regeneration. Plant Cell Tissue and Organ Culture 70: 71-81.

Yepes LM, Aldwinckle HS. 1994. Factors that affect leaf regeneration efficiency in apple, and effect of antibiotics in morphogenesis. Plant Cell Tissue and Organ Culture 37:257-269 